\title{
PENERAPAN KONSEP MVC PADA SISTEM PENJUALAN ONLINE DENGAN SISTEM KEAMANAN MENGGUNAKAN ALGORITMA RIJNDEAL
}

\author{
Saidul Irsyad $^{1}$, Arjon Samuel Sitio ${ }^{2}$ \\ ${ }^{1,2}$ STMIK Pelita Nusantara Medan \\ Jl. St.Iskandar Muda No. 1, Medan, Kode Pos 20154 \\ Email : irsyadkeling@ gmail.com ${ }^{1}$
}

\begin{abstract}
ABSTRAK
Dalam merancang sebuah website orang cenderung tidak menulis coding dari awal. Orang umumnya lebih memilih untuk menggunakan CMS, template engine atau framework untuk membuat pekerjaan mereka lebih ringan.Salah satu framework yang ringan, cepat dan gratis adalah Codeigniter. Konsep Model View Contoller atau biasa disingkat dengan MVC merupakan sebuah arsitektur dimana proses pada sistem dipisah menjadi tiga bagian dengan tugas-tugas dan tanggung jawab masing-masing. Konsep ini lebih memudahkan programmer dalam mengatur query database, manajemen kode, validasi data dan keamanan. Masalah keamanan sering kali kurang mendapat perhatian dari para pemilik dan pengelola toko online. Seringkali masalah keamanan berada di urutan kedua, atau bahkan di urutan terakhir dalam daftar hal-hal yang dianggap penting. Sistem login yang menggunakan database sebagai autentikasi user dan password sangat rentan untuk diretas oleh karena itu masih banyak pengguna internet yang masih meragukan keamanan sistem penjualan online. Algoritma Rijndael adalah algoritma kriptografi yang dapat melindungi data dengan baik. dalam implementasinya dan dinobatkan sebagai Advanced Encryption Standard (AES). Hasil dari penggunaan Konsep MVC dan Algoritma ini agar website lebih terstuktur dan tidak mudah diretas dan lebih aman dari berbagai serangan teknik hacking.
\end{abstract}

Kata kunci : Algoritma Rijndeal, Konsep MVC, Toko Online

\begin{abstract}
In designing a website people tend not to write coding from the start. People generally prefer to use CMS, template engines or frameworks to make their work lighter. One lightweight, fast and free framework is Codeigniter. The concept of Model View Contoller or commonly abbreviated as MVC is an architecture where the processes in the system are divided into three parts with their respective tasks and responsibilities. This concept makes it easier for programmers to manage database queries, code management, data validation and security. Security issues often receive less attention from owners and managers of online stores. Security issues are often second, or even last in the list of things that are considered important. Login systems that use databases as user and password authentication are very vulnerable to be hacked because there are still many internet users who still doubt the security of online sales systems. The Rijndael algorithm is a cryptographic algorithm that can protect data well. in its implementation and has been named the Advanced Encryption Standard (AES). The results of using this MVC concept and Algorithm to make the website more structured and not easily hacked and safer from various hacking attacks.
\end{abstract}

Keywords: Rijndeal Algorithm, MVC Concept, Online Store

\section{PENDAHULUAN}

Pada saat ini pengembangan dalam ilmu pengetahuan dan teknologi banyak memberikan kemudahan, khususnya bagi para pelaku bisnis,Toko Online atau yang sering di sebut dengan E-Commerce adalah salah satu konsep yangg sangat berkembang di dunia internet.

Namun masalah keamanan sistem sering kali kurang mendapat perhatian. Sistem login yang menggunakan database sebagai autentikasi user 
IN F O R M A I I A

Jurnal Informatika, Manajemen dan Komputer, Vol.11 No.2, Desember 2019

eISSN : 2580-3042

pISSN : 1979-0694

dan password sangat rentan untuk diretas oleh karena itu masih banyak pengguna internet yang masih meragukan keamanan sistem penjualan online.

Algoritma Rijndael adalah algoritma kriptografi yang dapat melindungi informasi dengan baik serta efisien dalam implementasinya. Algoritma Rijndel merupakan salah salah satu algoritma yang ditentukan oleh National Institute of Standards and Technology (NIST) sebagai pemenang dalam perlombaan memperebutkan kandidat AES (Advanced Encryption Standard).

Seiring berkembang nya teknologi dan informasi, umumnya dalam pemograman bahasa PHP, dalam membangun sebuah website orang cenderung tidak menulis coding dari awal. Orang pada umumnya menggunakan CMS, template engine atau framework untuk membuat pekerjaan mereka lebih mudah. Salah satu konsep yang dibuat oleh pakar pemrograman adalah memecah sebuah aplikasi berbasis web menjadi tiga bagian yaitu Model yang berkaitan dengan operasi pada basis data, View yang berhubungan dengan tampilan website dan terakhir Controller yang berhubungan dengan logika website dan mengendalikan alur data antara view dan controller konsep ini merupakan pengembangan dari konsep pemrograman berorientasi objek dan dalam pemrograman dikenal dengan MVC.

\section{METODOLOGI PENELITIAN}

Metode Penelitian adalah tahapan atau gambaran yang akan dilakukan dalam penelitian untuk mempermudah penelitian. Kerangka Kerja "Penerapan Konsep MVC (Model View Controller) pada penjualan online, serta implementasi algoritma Rijndeal untuk keamanan login dan database pada Toko Online dan pengujian menggunakan beberapa teknik hacking dibuat untuk memberikan gambaran serta kemudahan dalam melakukan penelitian. Berikut ini persiapan yang dilakukan sebelum penulis mulai melakukan penelitian.

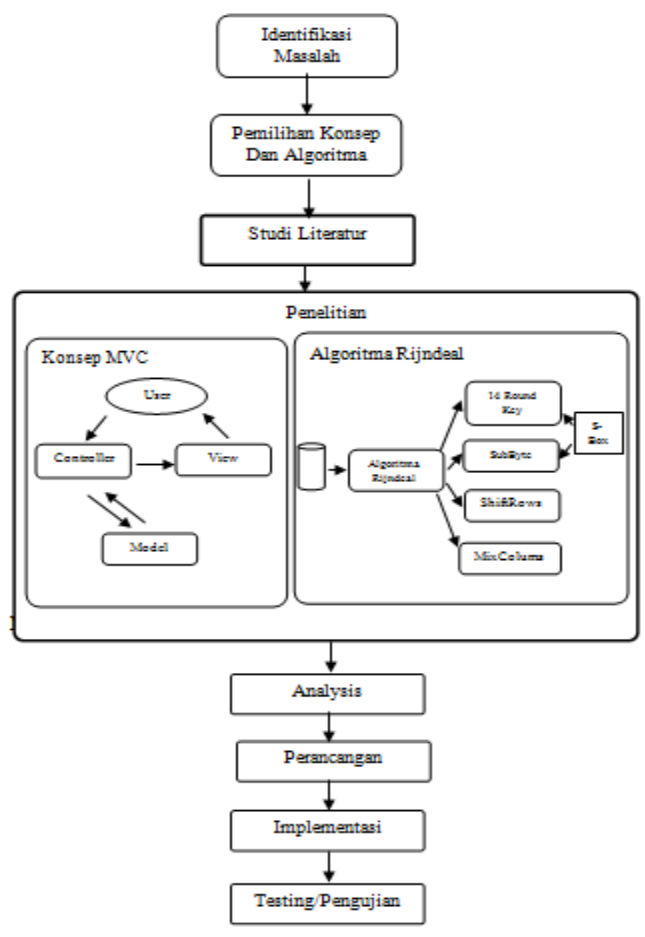

Gambar 1. Kerangka kerja penelitian

\section{HASIL DAN PEMBAHASAN}

a. Analisa Konsep MVC

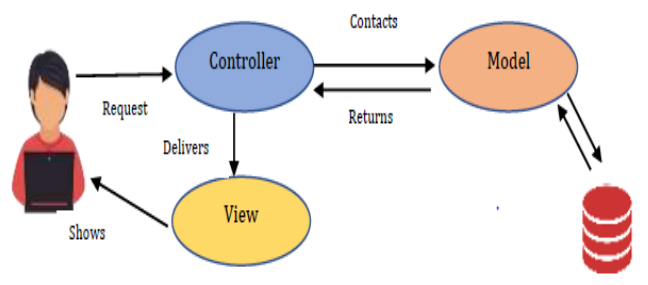

Gambar 2. Alur Konsep MVC

\section{1) Model}

biasanya berhubungan dengan data dan interaksi ke database atau webservice. Model juga merepresentasikan struktur data dari aplikasi yang bisa berupa basis data maupun data lain, misalnya dalam bentuk file teks, file XML maupun webservice. Biasanya didalam model akan berisi class dan fungsi untuk mengambil, melakukan update dan menghapus data website. Sebuah aplikasi web biasanya menggunakan basis data dalam menyimpan data, maka pada bagian Model biasanya akan berhubungan dengan perintah-perintah query SQL. 
IN F ORMA TIK

Jurnal Informatika, Manajemen dan Komputer, Vol.11 No.2, Desember 2019

eISSN : 2580-3042

pISSN : 1979-0694

2) View

merupakan bagian yang menangani presentation logic. Pada suatu aplikasi web bagian ini biasanya berupa file template HTML, yang diatur oleh controller. View berfungsi untuk menerima dan merepresentasikan data hasil dari model dan controller kepada user. View tidak memiliki akses langsung terhadap bagian model.

\section{3) Controller}

merupakan bagian yang mengatur hubungan antara bagian model dan bagian view. Pada controller terdapat class-clas dan fungsi-fungsi yang memproses permintaan dari View ke dalam struktur data di dalam model. Controller juga tidak boleh berisi kode untuk mengakses basis data Karena tugas megakses data telah diserahkan kepada model. Tugas controller adalah menyediakan berbagai variable yang akan ditampilkan di view, memanggil model untuk melakukan akses ke basis data, menyediakan penanganan kesalahn/error, mengerjakan proses logika dari aplikasi serta melakukan validasi atau cek terhadap input.

\section{b. Analisa Algoritma Rijndeal}

Algoritma Rijndael mempunyai 3 (tiga) parameter:

1. Plainteks adalah array yang berukuran 16byte, yang berisi data masukan.

2. Cipherteks adalah array yang berukuran 16byte, yang berisi hasil enkripsi.

3. Kunci adalah array yang berukuran 16-byte, yang berisi kunci cipher (disebutjuga chiper key).

Garis besar algoritma Rijndael yang beroperasi pada blok 128 bit dengan kunci 128 bit adalah sebagai berikut:

1. AddRoundKey, melakukan XOR antara state awal (plainteks) dengan chiper key. Tahap ini disebut juga initial round.

2. Putaran sebanyak $N r-1$ kali. Proses yang dilakukan pada setiap putaran adalah:

a. SubBytes adalah substitusi byte dengan menggunakan tabel substitusi ( $S$-Box).

b. ShiftRows adalah pergeseran baris-baris array state secara wrapping.

c. MixColumns adalah mengacak data di masing-masing kolom array state.

d. AddRoundKey adalah melakukan XOR antara state sekarang round key.

3. Final round, proses untuk putaran terakhir:
a. SubBytes

b. ShiftRows

\section{c. AddRoundKey}

\section{c. Transformasi SubBytes}

Transformasi SubBytes memetakan setiap byte dari array state dengan menggunakan tabel substitusi $S$-Box. Tidak seperti DES yang mempunyai $S$-Box berbeda pada setiapputaran, Rijndael hanya mempunyai satu buah. Tabel yang digunakan adalah:

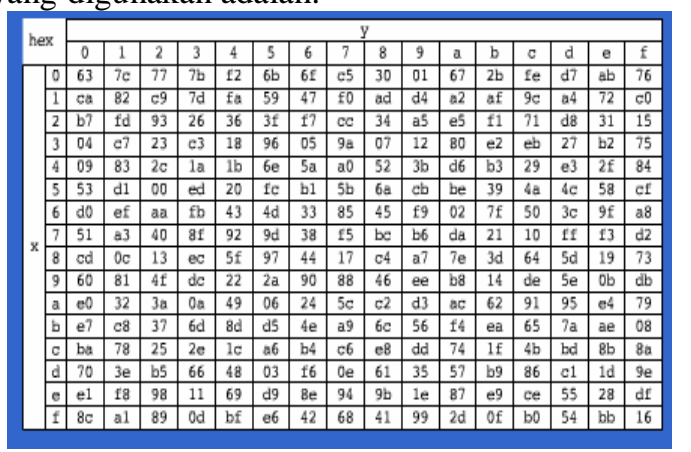

Gambar 3. Tabel S-Box Rijndael

Cara pensubstitusian adalah sebagai berikut:

jika setiap byte pada array state $\mathrm{S}[\mathrm{r}, \mathrm{c}]=\mathrm{xy}$, $\mathrm{xy}$ adalah digit heksa desimal dari nilai $\mathrm{S}[\mathrm{r}, \mathrm{c}]$, maka nilai substitusinya, dinyatakan dengan $\mathrm{S}^{\prime}[\mathrm{r}, \mathrm{c}]$, adalah elemen di dalam $S$-Box yang merupakan perpotongan baris $\mathrm{x}$ dengan kolom $\mathrm{y}$.

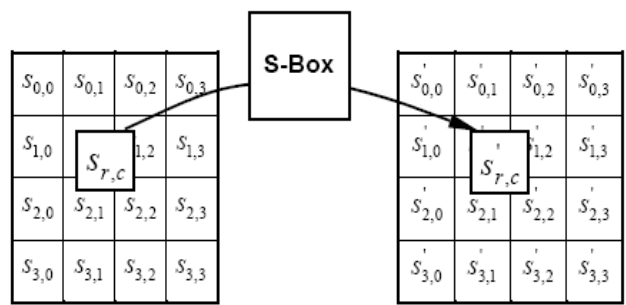

Gambar 4. Transformasi SubByte dengan S-Box

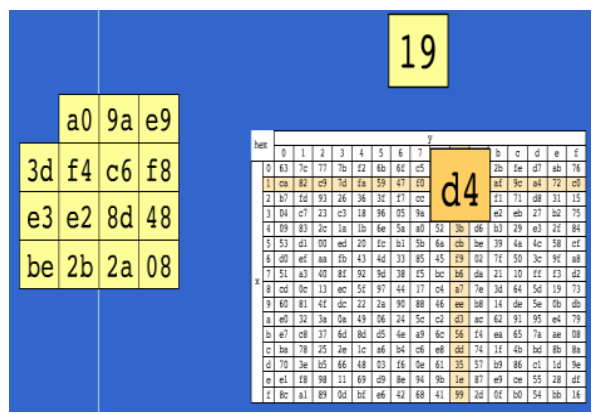

Gambar 5. Proses SubBytes

$$
\begin{array}{|l|l|l|l|}
\hline \mathrm{d} 4 & \mathrm{e} 0 & \mathrm{~b} 8 & 1 \mathrm{e} \\
\hline 27 & \mathrm{bf} & \mathrm{b} 4 & 41 \\
\hline 11 & 98 & 5 d & 52 \\
\hline \mathrm{ae} & \mathrm{f} 1 & \mathrm{e} 5 & 30 \\
\hline
\end{array}
$$

Gambar 6. Hasil SubBytes 
IN F ORMA T I K A

Jurnal Informatika, Manajemen dan Komputer, Vol.11 No.2, Desember 2019

eISSN : 2580-3042

pISSN : 1979-0694

\section{d. Transformasi ShiftRows}

Transformasi ShiftRows melakukan pergeseran secara wrapping pada 3 (tiga) baris terakhir dari array state. Jumlah pergeseran bergantung pada nilai baris $\mathrm{r}$. Baris $\mathrm{r}=1$ digeser sejauh 1 byte, baris $r=2$ digeser sejauh 2 byte, dan baris $r=3$ digeser sejauh 3 byte. Baris $r=0$ tidak digeser.
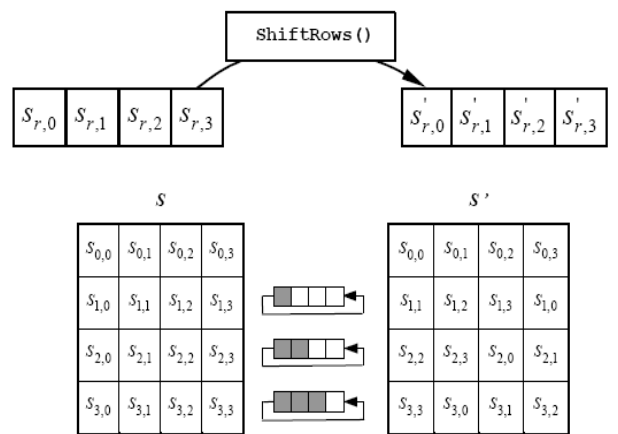

Gambar 7 Transformasi Shiftrows

Geser baris ke-1:

\begin{tabular}{|l|l|l|l|}
\hline $\mathrm{d} 4$ & $\mathrm{e} 0$ & $\mathrm{~b} 8$ & $1 \mathrm{e}$ \\
\hline 27 & $\mathrm{bf}$ & $\mathrm{b} 4$ & 41 \\
\hline 11 & 98 & $5 \mathrm{~d}$ & 52 \\
\hline ae & $\mathrm{f} 1$ & $\mathrm{e} 5$ & 30 \\
\hline
\end{tabular}

Hasil pergeseran baris ke-1 dan geser baris ke-2:

\begin{tabular}{|c|c|c|c|}
\hline $\mathrm{d} 4 \mathrm{e}$ & $\mathrm{eOb}$ & 88 le & \\
\hline & & 11 & \\
\hline 119 & 85 & $5 d 52$ & $\therefore$ rotate over 2 bytes \\
\hline aef & $\mathrm{f} 1 \mathrm{e}$ & e5 & \\
\hline
\end{tabular}

Hasil pergeseran baris ke-2 dan geser baris ke-3:

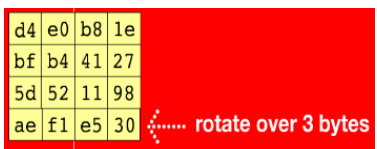

Hasil pergeseran baris ke-3 dan geser baris ke-4:

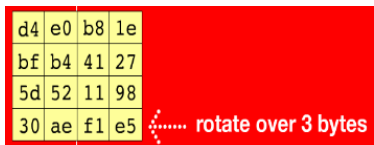

Gambar 8 Proses transformasi Shiftrows

$$
\begin{array}{|l|l|l|l|}
\hline \mathrm{d} 4 & \mathrm{e} 0 & \mathrm{~b} 8 & 1 \mathrm{e} \\
\hline \mathrm{bf} & \mathrm{b} 4 & 41 & 27 \\
\hline 5 \mathrm{~d} & 52 & 11 & 98 \\
\hline 30 & \text { ae } & \text { f1 } & \text { e5 } \\
\hline
\end{array}
$$

Gambar 9 Hasil dari ShiftRows

\section{e. Tranformasi MixColumns}

Transformasi MixColumns mengalikan setiap kolom dari array state dengan polinoma $(x) \bmod (x 4+1) . \quad$ Setiap kolom diperlakukan sebagai polinom 4-suku pada $\mathrm{GF}(28)$. Polinom a(x) yang ditetapkan adalah:

$$
a(x)=\{03\} \times 3+\{01\} \times 2+\{01\} x+\{02\}
$$

Transformasi ini dinyatakan sebagai perkalian matriks:

$$
\begin{gathered}
s^{\prime}(x)=a(x) \otimes s(x) \\
{\left[\begin{array}{l}
s 0^{\prime} \\
s 1^{\prime} \\
s 2^{\prime} \\
s 3^{\prime} \\
s 4^{\prime}
\end{array}\right]=\left[\begin{array}{llll}
02 & 03 & 01 & 01 \\
01 & 02 & 03 & 01 \\
01 & 01 & 02 & 03 \\
03 & 01 & 01 & 02
\end{array}\right]} \\
s_{0, c}^{\prime}=\left(\{02\} \bullet s_{o, c}\right) \oplus\left(\{03\} \bullet s_{1, c}\right) \oplus s_{2, c} \oplus s_{3, c} \\
s_{1, c}^{\prime}=s_{0, c} \oplus\left(\{02\} \bullet s_{1, c}\right) \oplus\left(\{03\} \bullet s_{2, c}\right) \oplus s_{3, c} \\
s_{2, c}^{\prime}=s_{0, c} \oplus s_{1, c} \oplus\left(\{02\} \bullet s_{2, c}\right) \oplus\left(\{03\} \bullet s_{3, c}\right) \\
s_{3, c}^{\prime}=\left(\{03\} \bullet s_{0, c}\right) \oplus s_{1, c} \oplus s_{2, c} \oplus\left(\{02\} \bullet s_{3, c}\right)
\end{gathered}
$$

$\left.\begin{array}{|l|}\hline \mathrm{d} 4 \\
\hline \mathrm{bf} \\
\hline 5 \mathrm{~d} \\
\hline 30\end{array} \bullet \bullet \begin{array}{llll}02 & 01 & 01 & 03 \\
03 & 02 & 01 & 01 \\
01 & 03 & 02 & 01 \\
01 & 01 & 02 & 03\end{array}\right]=$\begin{tabular}{l}
04 \\
\hline 66 \\
\hline 81 \\
\hline e5 \\
\hline
\end{tabular}

Gambar 10 Operasi MixColumns

$$
\begin{array}{|l|l|l|l|}
\hline 04 & \text { e0 } & 48 & 28 \\
\hline 66 & \mathrm{cb} & \mathrm{f} 8 & 06 \\
\hline 81 & 19 & \mathrm{~d} 3 & 26 \\
\hline \text { e5 } & 9 \mathrm{a} & 7 \mathrm{a} & 4 \mathrm{c} \\
\hline
\end{array}
$$

Gambar 11 Hasil keseluruhan MixColumns

\section{Transformasi AddRoundKey}

Transformasi ini melakukan operasi XOR terhadap sebuah round key dengan arraystate, dan hasilnya disimpan di array state.

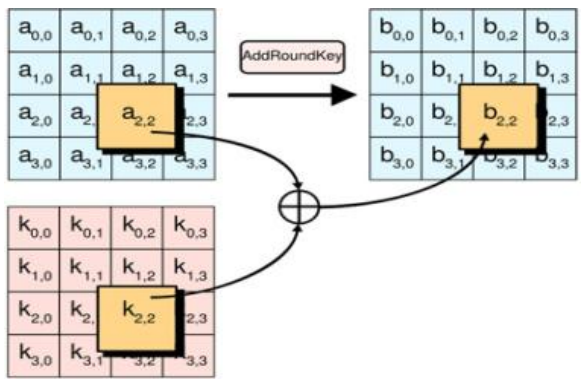

Gambar 12 Transformasi AddRoundKey 
IN F ORMA T I K A

Jurnal Informatika, Manajemen dan Komputer, Vol.11 No.2, Desember 2019

eISSN : 2580-3042

pISSN : 1979-0694

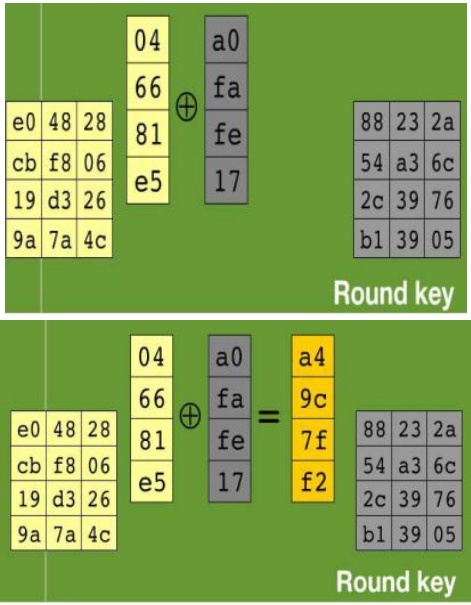

$$
\begin{array}{|c|c|c|c|}
\hline \mathrm{a} 4 & 68 & 6 \mathrm{~b} & 02 \\
\hline 9 \mathrm{c} & 9 \mathrm{f} & 5 \mathrm{~b} & 6 \mathrm{a} \\
\hline 7 \mathrm{f} & 35 & \mathrm{ea} & 50 \\
\hline \mathrm{f2} & 2 \mathrm{~b} & 43 & 49 \\
\hline
\end{array}
$$

Gambar 13 Hasil AddRoundKey

\section{f. Ekspansi Kunci}

Algoritma Rijndael melaksanakan cipherkey dan membuat suatu ekspansi kunci untuk menghasilkan suatu key schedule. Jika ekspansi kunci yang diperlukan Rijndael $\mathrm{Nb}(\mathrm{Nr}+1)$ word, sehingga bisa digunakan AES 128 bit, maka $4(10+1)=40$ word $=44 \times 32$ bit $=1408$ bit subkey. Ekspansi dari 128 menjadi 1408 bit subkey, proses ini disebut dengan key schedule. Subkey ini diperlukan karena setiap round merupakan suatu inisial dari $\mathrm{Nb}$ word untuk $\mathrm{Nr}=0$ dan $\mathrm{Nb}$ untuk $\mathrm{Nr}=1,3$ untuk $\mathrm{Nr}=2, \ldots ., 11 \mathrm{Nb}$ untuk $\mathrm{Nr}=10$, dari operasi ini akan didapatkan schedule kunci yang berisi array linier 4 byte word $\left(\mathrm{w}_{\mathrm{i}}\right), 0=\mathrm{i}(\mathrm{Nr}+1)$.

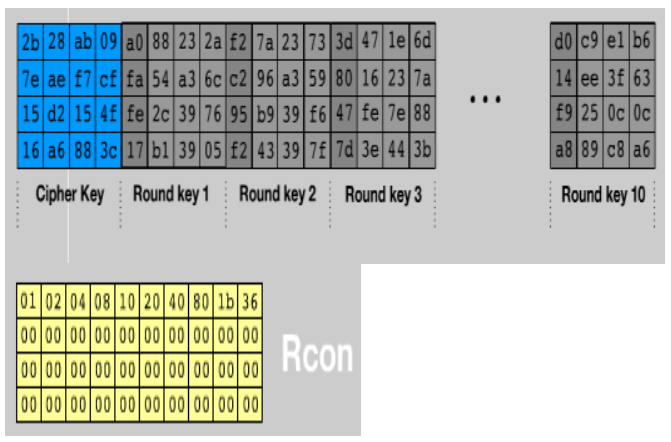

Gambar 14 Proses ekspansi kunci
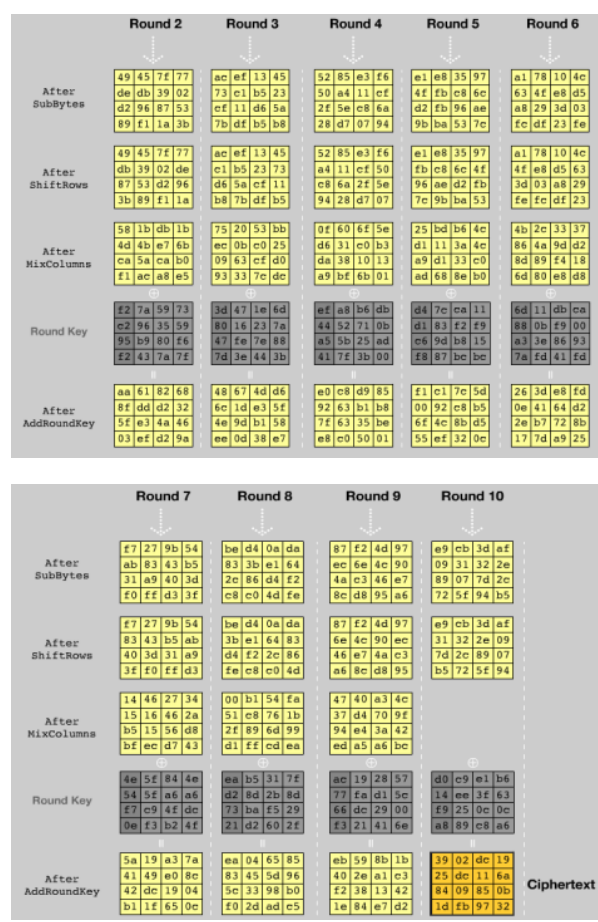

Gambar 15 Proses Algoritma Rijndeal

\section{g. Perancangan Sistem}

1. Use Case Diagram

Use Case adalah gambaran fungsioalitas dari suatu sistem, sehingga pengguna sistem paham dan mengerti mengenai kegunaan sistem yang akan di bangun . Aktor-aktor yang melakukan prosedur dalam sistem dan respon yang ditanggapi oleh sistem terhadap prosedur yang di lakukan oleh aktor di jelaskan dalam skenario use case diagram pada gambar berikut :

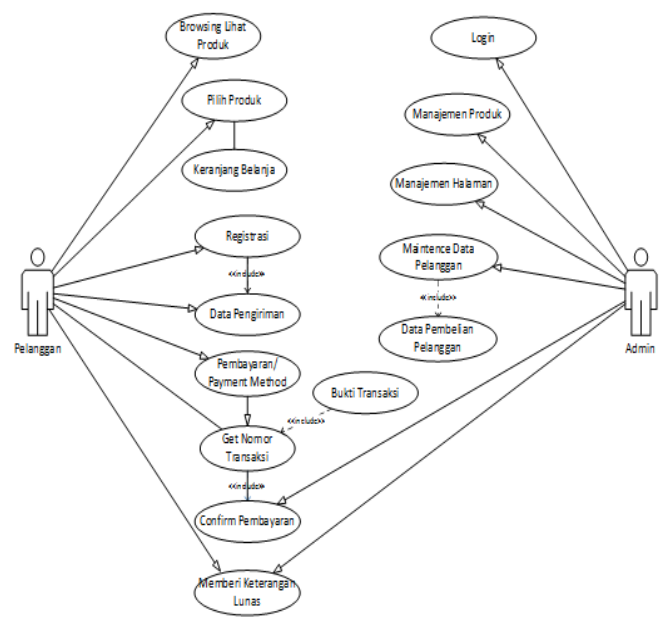

Gambar 16 Use Case Diagram 
IN F ORMA T I K A

Jurnal Informatika, Manajemen dan Komputer, Vol.11 No.2, Desember 2019

eISSN : 2580-3042

pISSN : 1979-0694

\section{Activity Diagram}

Activity Diagram menggambarkan berbagai alir aktivitas dalam sistem yang sedang dirancang, bagaimana masing-masing alir berawal, decision yang mungkin terjadi, dan bagaimana mereka berakhir. Activity diagram juga dapat menggambarkan proses paralel yang mungkin terjadi pada beberapa eksekusi.

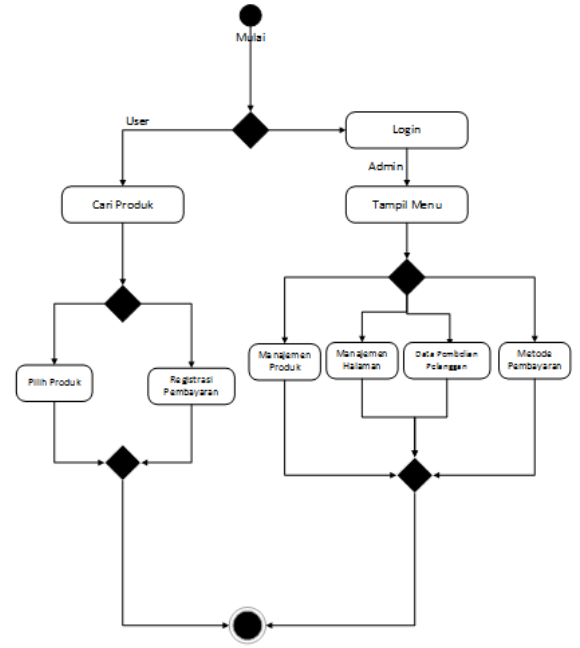

Gambar 17 Activity Diagram

\section{Sequence Diagram}

Sequence Diagram adalah suatu diagram yang menggambarkan interaksi antar obyek dan mengindikasikan komunikasi diantara obyekobyek tersebut. Berikut sequence diagram pada website Toko Online.

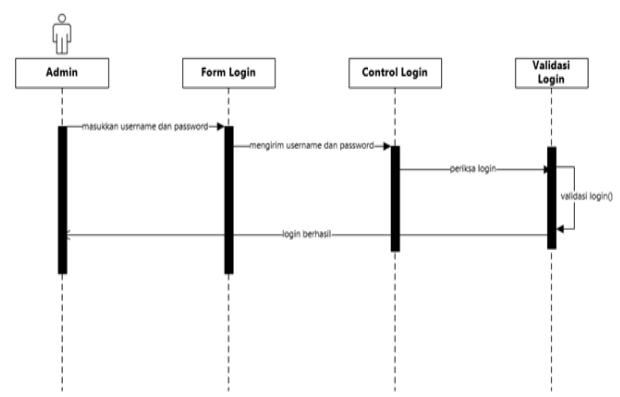

Gambar 18 Sequence Diagram

\section{Class Diagram}

Class Diagram adalah diagram yang digunakan untuk menampilkan beberapa class yang ada dalam sistem perangkat lunak yang di kembangkan. Class Diagram menunjukkan hubungan antar classdalam sistem yang sedang dibangun dan bagaimana mereka saling berkolaborasi untuk mencapai suatu tujuan.

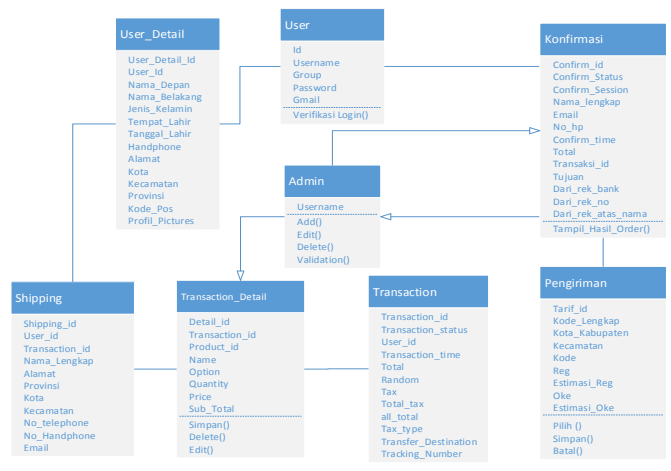

Gambar 19 Class Diagram.

Perancangan antarmuka digambarkan dengan HIPO (Hierarchy Plus Input-Process-Output).

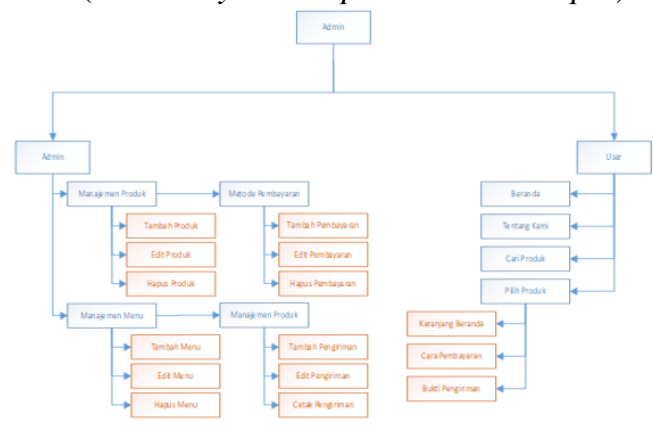

Gambar 20 HIPO Diagram

\section{h. Implementasi Sistem}

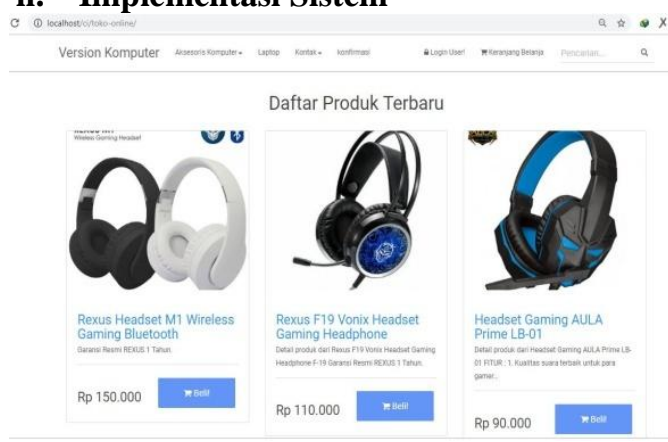

Gambar 21 Halaman Utama Website

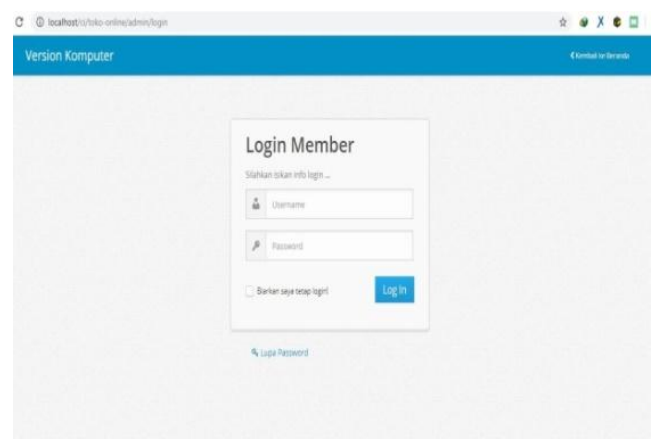

Gambar 22 Login Admin 
I N F O R M A T I K A

Jurnal Informatika, Manajemen dan Komputer, Vol.11 No.2, Desember 2019

eISSN : 2580-3042

pISSN : 1979-0694

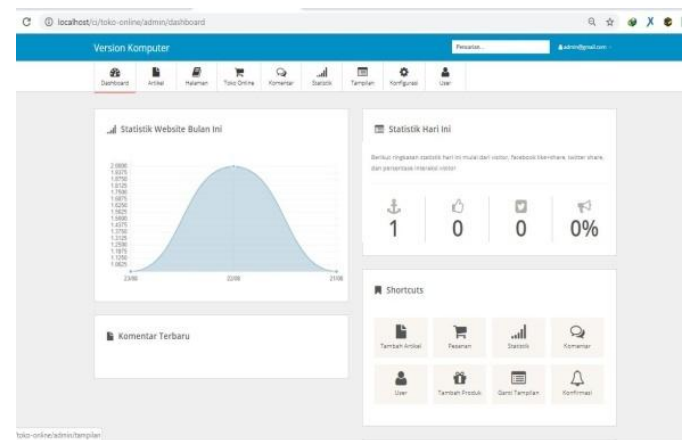

Gambar 22. Halaman Admin setelah login

Pengujian Keamanan Dengan Serangan SQLInjection

Terdapat beberapa cara yang dapat digunakan untuk melakukan pengujian terhadap kemanan website. Salah satunya adalah dengan melakukan SQL Injection.

Pada Website akan dimasukan sintaks - sintaks sql pada form login. Contoh sintaks yang digunakan adalah "or", " $1=1$ ", " $0=0$ ". Berikut beberapa skenario yang akan diuji dalam penelitian ini.

Pada pengujian ini sebagai contoh website skyplus-travels.com akan di uji menggunakan sql-injection.

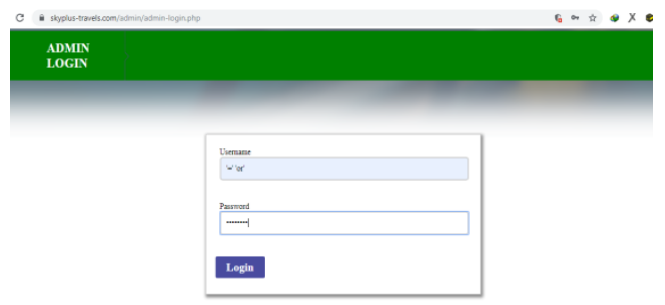

Gambar 23 Website login website yang diuji dengan sql-injection
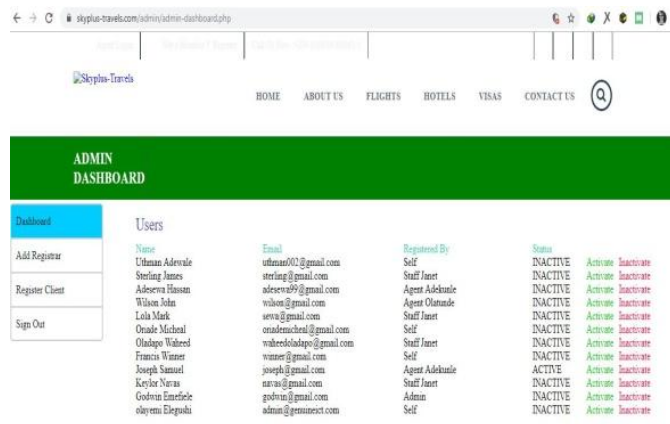

Gambar 24 Tampilan website yang berhasil di retas
Sedangkan website yang menggunakan algoritma rijndeal tidak berhasil di retas dengan menggunakan sql-injection.

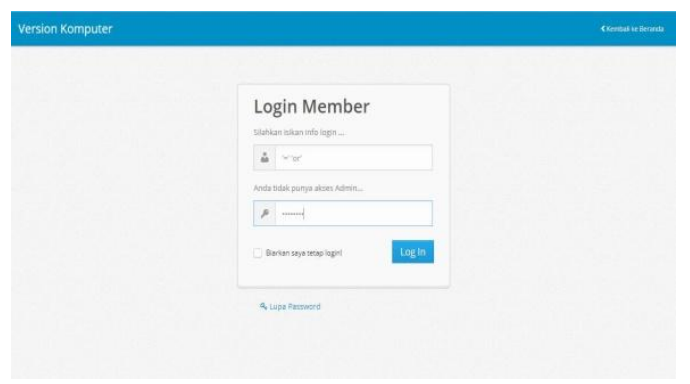

Gambar 25 Tampilan web gagal di retas

\section{KESIMPULAN}

Berdasarkan hasil penelitian dalam Penerapan Konsep MVC Pada Penjualan Online Dengan Sistem Keamanan Menggunakan Algoritma Rijndeal, dapat disimpulkan beberapa hal sebagai berikut:

1. Konsep Model View Controller (MVC) lebih memudahkan programmer dalam mengatur query database, manajemen kode, validasi data dan keamanan.

2. Coding yang dihasilkan dengan menggunakan Konsep MVC menjadi lebih terstruktur, efisien dan mudah di lakukan pengembangan.

3. Berdasarkan hasil pengujian Algoritma Rijndeal dapat digunakan pada login untuk memproteksi serangan hacking seperti SQLInjection.

\section{REFERENSI}

Pastima Simanjuntak, Arwin Kasnady, Desember (2016) Analisis Model View Controller (MVC) Pada Bahasa PHP: Jurnal ISD Vol.2 No.2 e-ISSN : 2582-5114.

Kartika Imam Santoso, Wahyu Priyoatmoko, (2016) Pengamanan Data My SQL Pada Ecommerce dengan Algoritma AES 256. Jurnal Sistem Informasi Indonesia, 1 Nopember 2016

Niria Laila1, Anita Sindar RMS, Implementasi Steganografi LSB Dengan Enkripsi Vigenere Cipher Pada Citra, ScientiCO : Computer Science Informatics Journal Vol. 1, No. 2, hal, 47-5, 2018.

Sugeng Murdowo, Mengenal Proses Perhitungan Enkripsi Menggunakan Algoritma Kriptografi Advance Encription Standard (AES) Rijndeal : INFOKAM Nomor 1/ Th. X/Maret/2014. 